\title{
Introduction to Special Issue: The Gift in India in Theory and Practice
}

\author{
Anthony Cerulli ${ }^{1} \cdot$ Miriam Benteler $^{2}$
}

Published online: 4 July 2018

(C) Springer Nature B.V. 2018

Exchange is fundamental to every society. As the Royal Swedish Academy of Sciences declared in its announcement of the 2016 Nobel Prize in Economic Sciences, "Modern economies are held together by innumerable contracts." ${ }^{1}$ The contracts recognized in this statement are the bonds that subtend relationships between people and institutions in most societies nowadays. These include legal employment, taxation, and insurance agreements, as well as the innumerable exchange agreements that shape the contours of many people's daily lives in modern societies. Like the Nobel Prize committee-and, first and foremost, the Nobel Prize winners-Marcel Mauss also drew our attention to "contract and exchange" in his famous study, "Essai sur le don: forme et raison de l'échange dans les sociétés archaïques" (1923-24). His work, however, illustrates exchange and contracts of a different kind. On the basis of comparative analysis of different societies and different times, he argued that the exchange of things between people and groups builds relationships. At their core, exchange systems in human societies have been based on obligations to give and receive. Mauss observed that a sense of reciprocity undergirded the exchanges that create bonds of prosperity, cooperation, and solidarity between groups of people. He applied his analysis across all social

\footnotetext{
1 "Press Release: The Prize in Economic Sciences 2016," The Royal Swedish Academy of Sciences, Stockholm, October 10, 2016. Available at: https://www.nobelprize.org/nobel_prizes/economic-sciences/ laureates/2016/press.html.
}

Anthony Cerulli

acerulli@wisc.edu

Miriam Benteler

miriambenteler@web.de

1 University of Wisconsin-Madison, Madison, Wisconsin, USA

2 Weimar, Germany 
domains, so that the obligation to reciprocate was not only obvious in the area of economics, but also in religion, politics, and entertainment. According to Mauss (2011: 1, 66), in any one of these social domains the so-called gift, contrary to the modern understanding of the term-which posits the bestowal of something gratuitously, for nothing, with no expectation of return-was in fact motivated both by self-interest and social concern for others. It is good to give "gifts," he said, not because the act of gift giving reveals a person's altruism or selflessness, but because that act of gifting something will come back to the giver since it creates a lasting bond between giver and receiver. Contracts in modern societies certainly also create bonds, but these are different from those created by gift exchange. Modern contracts create, above all, economic bonds, bonds between persons and things. These bonds are not permanent: if the contract ends, the relation ends. In gift exchange, relations are "uneconomic." They are created between people, and they are lasting, oftentimes even being transmitted from generation to generation.

Drawing on C. A. Gregory's (2015) definition of gifts and gift exchange, in "The Gift and the Given," Eduard Viveiros de Castro probes the differences between relations and their establishment in gift and commodity systems: "In a regime where things and people assume the form of objects, relations are exteriorized, detached from persons in the form of rights. All relations must be converted into rights in order to be recognized, just as commodities must have prices to be exchanged; rights and duties define the relative value of persons, just as prices define the exchange rate of things" (2009: 248). Rights are, for example, fixed in contracts. The equivalent of rights in a gift economy, Viveiros de Castro points out, are classificatory kinship terms. While relations in a commodity economy (where things and people have the form of objects) are handled in terms of rights, in a gift economy (where things and people have the form of people), relations are kinship relations. Thus, gift exchange and kinship (and animism) may be understood as "different names for the same personification process" (Viveiros de Castro 2009: 246), a process in which persons and things assume the social form of persons. Even without diving into the depths of his "Nano-essays on kinship and magic," as he calls them, the centrality of gift exchange, the impossibility to separate gift exchange from other analytically separable "spheres," the dangers of viewing gift exchange from the perspective of commodity exchange, and the inseparability of gifts/objects and people in gift economies are, we think, apparent.

The present volume continues the nearly century-old exploration of gift giving following Mauss's study. It focuses on India, however, where Mauss's notions of the gift and gift giving are at once analytically useful and problematic. The research in the six articles in this volume combines ethnography and anthropological theory with philological attention to the deployment of old texts about giving and receiving in modern times. Throughout Indian history, we find systems of gift exchange existing alongside what are known today as commodity economies. Gift exchange in India permeates nearly every sphere of social interaction. It is central to Indian life. Indeed, as the contributing authors' studies in this special issue illustrate, social life in India can hardly be imagined without considering it.

Dāna, dakșiṇa, prasāda, upagrāha, upahāra - this list of some of the many words used in India for different types of "gifts" gives the impression that there are 
multiple forms and varieties of gifts and gift exchange in the region: people exchange different material goods, knowledge, wives, money, friendship, and more, in multiple contexts and with various transactors. Indeed scholars concerned with philosophy, politics, religion, education, and economics have been deliberating gift exchange in theory and practice in India for a long time, as, to cite a well-known example, we see in discussions of dānadharma, the classical obligation to give described in Sanskrit and Pali literature. Hindu Dharmaśāstra texts were actually important to Mauss's (2011: 54) pioneering work to support his thesis that the development of modern markets was preceded by a time characterized by obligatory gift exchange and the inseparability of persons and things. Mauss's discussion anticipated one of the most fundamental discussions in anthropological exchange theory concerning the distinction between gift and commodity exchange (Gregory 1994, 2015; Appadurai 1986; Strathern 1992). With the dhārmic law of dāna ("giving") as a point of some disputation for Mauss, a kind of Indian challenge to his general theory of the gift itself became a starting point for the discussion of the paradox of the "free" or "pure" gift, of the "Indian gift" as it is often called, for anthropologists and philologists investigating Indian society, religion, and anthropology.

Studies on the Indian gift, a gift that expressly prohibits reciprocity, have evoked many theoretical discussions about the nature of the gift and gift exchange. These discussions are ongoing in anthropology and other disciplines (Parry 1986; Michaels 1997; Laidlaw 2000), and the topic of gift theory — as it was articulated by Mauss and others after him-is pointedly addressed in the contributions to this volume. Other types of gift exchange in India, moreover, have served to challenge and counter old ideas about the gift in India and to develop new social scientific perspectives, such as in the areas of caste (Raheja 1989; Gregory 1992) and kinship (Levi-Strauss 1969; Dumont 1983). The present collection does not concentrate on the Indian gift per se, but on Indian gifts generally, and explores the theory, types, and functions of gift exchange in India.

New types of gift giving are constantly emerging in India, while old ones are changing in form and function, though not necessarily in meaning, shaping the outlines of contemporary life. The articles in this volume deal with gift exchange in very different contexts - in medicine and kinship, tourism and marriage, music, finance, and credit. This arrangement was deliberate. It allows for a dual exploration of the gift that simultaneously encourages innovative theorizations that can speak, at a metadiscursive level, to similar questions being broached in dissimilar contexts. As a result, on the one hand, each contribution suggests a different theoretical scenario and argument. On the other hand, all of the articles basically address the same questions, questions that have occupied social scientists studying exchange for decades: How can we define the difference between gifts and commodities, and to what extent are gift exchanges and market exchanges intertwined? How can we describe the networks initiated and strengthened by gift exchange and the intimate, though often hierarchical, relationships between those involved in gift economies? Given the variety of approaches and ethnographic data used in these articles, can we speak of a common theory of gift exchange in India that may be deployed usefully across different regions and cultural contexts? Another recurring theme that unifies 
the studies is Mauss's general theory of the gift. Each author engages Mauss's classic study in some way. And each article in one way or another discusses the question of hierarchy in the giving, receiving, and returning of gifts.

In "Toward an Anthropology of Exchange in Tamil Nadu," Isabelle Clark-Decès examines exchange and gift giving in Tamil Nadu in different times and contexts. Basing her analysis on historical and ethnographic sources, Clark-Decès focuses on the metafunctions of Tamil exchange. In addition to the gifting of kings in the medieval period, she looks at exchange among castes in rural South India and gift giving in the context of kinship, especially dowry and the question of reciprocity. Different as the described exchanges are with respect to time, exchange objects, and givers and receivers, Clark-Decès shows that in the political and family spheres Tamil gift exchange creates bonds that are characterized by and inseparable from ideas and concepts of superiority and inferiority. Gifts are thus a means of social distinction; they show one's social standing, one's social difference, and/or similarity to others. Clark-Decès argues that this happens in Indian societies that focus on the whole, which is always a hierarchically structured whole. Thus, people have rights in gifts/shares from relatives, from landlords, and from kings, and, no matter how big or small these gifts/shares are, they thereby form part of this hierarchically constituted whole.

Hierarchy is also important in the exchange Rolf Groesbeck examines in his article, "Gift as Devotion, Lesson as Tuition: Transactions Among Temple and Dance-Drama Drummers in Kerala." Against the background of the question of the difference between exchanges of commodities and so-called gifts, Groesbeck analyzes gifts given to music teachers by their students. In the traditional model, music is taught privately, and gifts given by students to their teachers at important points of the teaching period/process-known as guru dakșina — and the way gifts are given in ritual contexts are to be understood as acts of submission and devotion. With guru dakșina students do not compensate their teachers for the gift of music instruction, the gift of expert musical knowledge, inherent in the work of teachingthis is not considered possible. Rather, guru dakșina physically exhibits the asymmetrical nature of the teacher-student relationship, displaying student indebtedness and marking this relationship as ongoing. In the state arts institutions of modern Kerala, such as Kalāmaṇạalam, the focus of Groesbeck's article, music lessons are paid by fees. The giving of guru dakșina, however, has not been abandoned. It exists alongside the payment of fees in this institutional context. Gifts and commodities are thus not mutually exclusive. They coexist, sometimes comfortably and sometimes uneasily.

The gift of knowledge is a cornerstone in the context of classically trained medical practitioners in South India, as Anthony Cerulli's article, "Gifting Knowledge for Long Life," argues. This article looks at Āyurvedic healthcare in Kerala and examines the nature of unilateral giving among Brāhmaṇa physicians and their patients, thereby addressing the issue of the Indian gift and the question of the relationship between classical texts and everyday-life practice. Cerulli questions whether or not we can regard the exchange of knowledge in doctor-patient meetings in this setting as gift giving. He additionally asks whether or not a gift of knowledge in this South Indian variety of Āyurveda, given and received for the improvement of 
physical wellbeing and long life, is in line with the oft-called Indian gift identified in classical Sanskrit treatises about the "dharma of gifts" (dānadharma). Questions of generosity and medical efficacy in view of classical dâna are linked to Mauss's theory of gift exchange and the ways in which the Kerala physicians whom Cerulli observes actually practice the Sanskrit medical classics of $\bar{A} y u r v e d a$ in their daily medical work.

If gift exchange between physicians and patients in the medical context of Cerulli's analysis wrestles with the asymmetry and unidirectionality of the Indian gift, where reciprocity is barred, the exchange of credits among relatives, friends and neighbors, which is the focus of Miriam Benteler's article "Money, Money, Money: Gift Exchange and Credit Giving in Coastal Kerala," rests on the very ideas of reciprocity, interdependence, and mutuality. The taking and giving of credits among relatives, friends, and acquaintances, known as katam ("debt"), is a common and absolutely necessary part of everyday life in the coastal Kerala village where Benteler conducted fieldwork. Because Malayāḷ fishermen and craftsmen have, on the one hand, fluctuating incomes and are, on the other hand, obliged to spend large amounts of money for things such as life-cycle rituals or their children's education, Benteler demonstrates that the giving of credits among people who stand in close relation to each other can be understood as a kind of gift exchange. Drawing on Anjum Alvi's (1999) distinction between gift and commodity exchange, and comparing the giving of credits and the collection of money from guests at marriages and other ceremonial occasions, Benteler shows that although the aim of kațam exchange is the money itself, relationships undoubtedly form the necessary bases of katam and are strengthened and confirmed by the giving of credits.

The research of Karin Polit and Emera Bridger Wilson takes us from the south of India to the north and from more traditional types of exchanges to more recently developing ones. Both authors show how gifts are used to construct and express certain ideas - such as romantic love in Polit's case study and self-respect in Bridger Wilson's. In "Gifts of Love and Friendship: On Changing Marriage Traditions, the Meaning of Gifts, and the Value of Women in the Garhwal Himalayas," Karin Polit juxtaposes obligatory gifts given in Garhwal at official occasions (for example, at weddings) with the exchange of small gifts, such as cards, posters, and knickknacks, that circulate nowadays among young Garhwalis. Polit shows that formal gift giving among relatives is part of a normative order, serves to regulate social relationships among families, and has a political dimension, as the shift from bride-price to dowry and the changing perception of women indicates. In contrast, exchanges among young, educated Garhwali people, who often experience the normative framework as constraining, allow for the expression of individual emotions and voluntary, nonobligatory giving. Contemporary values of love and friendship are thus negotiated and challenged by this gift-giving practice among Garhwal's youth.

In "The Gift of Respect: Tourist Gift Giving and the Construction of Self-Respect Among Authorized Sightseeing Rickshaw Drivers in Bharatpur, India," Emera Bridger Wilson shows how tourism workers at Keoladeo National Park use gifts they receive from tourists in the park and fees for their services-money (tips), photos, letters, clothes and other things-to oppose social and economic marginalization they experience from other castes in the area and surrounding 
neighborhoods. Rickshaw drivers establish connections with tourists, Bridger Wilson argues, that often go beyond just driving and guiding people around the park, and these interactions involve both material and symbolic elements of gift exchange. Although longstanding relationships rarely evolve beyond the short encounters rickshaw drivers have with the park's tourists, gifts that tourists give to their drivers have lasting importance. The drivers cherish the objects they receive from tourists (especially from Western tourists), display them proudly to their colleagues, and thereby reimagine their own social positions by using them to create narratives of self-respect.

We are delighted to continue the conversation about the gift in India in both theory and practice with this special issue. The bonds engendered and sustained amongst diverse groups and peoples in contemporary India, as each one of these unique ethnographically grounded studies illustrates, are gainfully and illuminatingly explored through the analytical lens of gift exchange.

In closing, it is with heavy hearts that we dedicate this issue to our colleague, Isabelle Clark-Decès, who passed away in 2017 while working in North India. As her article in this volume attests, she was masterful at blending ethnographic narratives and theoretical insights. Isabelle was a delightful, hard-working, and kind collaborator, and she will be dearly missed.

\section{References}

Alvi, Anjum. 1999. "Bearers of Grief: Death, Women, Gifts, and Kinship in Muslim Punjab." Ph.D. dissertation, Freie Universität Berlin.

Appadurai, Arjun. 1986. "Introduction: Commodities and the Politics of Value." In Arjun Appadurai, ed., The Social Life of Things: Commodities in Cultural Perspective, 3-63. Cambridge: Cambridge University Press.

Dumont, Louis. 1983. Affinity as a Value: Marriage Alliance in South India, with Comparative Essays on Australia. Chicago: University of Chicago Press.

Gregory, C. A. 1992. "The Poison in Raheja's Gift: A Review Article.” Social Analysis 32: 95-110.

Gregory, C. A. 1994. "Exchange and Reciprocity." In Tim Ingold, ed., Companion Encyclopaedia of Anthropology, 911-39. London, New York: Routledge.

Gregory, C. A. 2015 [1982]. Gifts and Commodities. Chicago: University of Chicago Press.

Laidlaw, James. 2000. "A Free Gift Makes No Friends." The Journal of the Royal Anthropological Institute 6, 4: 617-34.

Lévi-Strauss, Claude. 1969 [1949]. The Elementary Structures of Kinship (trans. James Harle Bell and John Richard von Sturmer; ed. Rodney Needham). Boston: Beacon Press.

Mauss, Marcel. 1923-24. "Essai sur le don: forme et raison de l'échange dans les sociétés archaïques." L'Année Sociologique (ns) 1: 30-186.

Mauss, Marcel. 2011 [1923-24]. The Gift: Forms and Functions of Exchange in Archaic Societies (trans. Ian Cunnison). Mansfield Centre: Martino Publishing.

Michaels, Axel. 1997. "Gift and Return Gift, Greeting and Return Greeting in India: On a Consequential Footnote by Marcel Mauss." Numen 44, 3: 242-69.

Parry, Jonathan. 1986. "The Gift, the Indian Gift and the 'Indian Gift'." Man (ns) 21, 3: 453-73.

Raheja, Gloria Goodwin. 1989. "Centrality, Mutuality and Hierarchy: Shifting Aspects of Inter-Caste Relationships in North India." Contributions to Indian Sociology (ns) 23, 1: 79-101.

Strathern, Marilyn. 1992. "Qualified Value: The Perspective of Gift Exchange." In Caroline Humphrey and Stephen Hugh-Jones, eds., Barter, Exchange and Value: An Anthropological Approach, 169-91. New York: Cambridge University Press.

Viveiros de Castro, Eduardo. 2009. "The Gift and the Given. Three Nano-Essays on Kinship and Magic." In Sandra Bamford and James Leach, eds., Kinship and Beyond: The Genealogical Model Reconsidered, 237-68. New York: Berghahn Books. 